\title{
Evaluation of the Physico-Chemical and Biological Stability of SB8 (Aybintio), a Proposed Biosimilar to Bevacizumab, Under Ambient and In-Use Conditions
}

Dongkuk Park · Jihyun Kim · Jihoon Yun · Su Jin Park

Received: July 6, 2020 / Published online: August 20, 2020

(C) The Author(s) 2020

reducing capillary electrophoresis-sodium dodecyl sulfate, imaged capillary isoelectric focusing), biological activity [vascular endothelial growth factor (VEGF) neutralization assay, VEGF binding assay] and potential safety impact properties (subvisible particulates, submicronic aggregation by dynamic light scattering) were determined.

Results: All stability-indicating criteria including those for biological activity were met for both unopened vials at ambient condition and for in-use conditions of opened vials as well as both dilutions. No noteworthy changes in terms of physicochemical stability, biological activity and properties with a potential safety impact occurred.

Conclusion: Under the studied aspetic extreme conditions, SB8 was stable. Our data may support advanced SB8 preparation and may help prevent SB8 wastage because of exceptional temperature excursions or unused product. Sterility assurance is the responsibility of the user and is of utmost importance when opened or diluted SB8 is not immediately used.

Keywords: Ambient temperature; Avastin; Aybintio; Bevacizumab; Biosimilar; In-use; Oncology; SB8; Stability; Storage

D. Park · J. Kim · J. Yun · S. J. Park $(\bowtie)$ Quality Evaluation Team, Samsung Bioepis Co., Ltd., 107, Cheomdan-daero, Yeonsu-gu, Incheon 21987, Republic of Korea

e-mail: sujin8171.park@samsung.com 
Key Summary Points

Why carry out this study?

Stability of unopened SB8 vials stored outside of $2-8{ }^{\circ} \mathrm{C}$ or of opened vials stored at any condition is unknown, and limited data exist on dilutions

Advance preparation of SB8 may avoid unnecessary delays in the treatment of patients and reduce drug wastage

The physicochemical stability, biological activity and potential safety implications of diluted SB8 and of opened and unopened vials were evaluated

\section{What was learned from the study?}

The physicochemical stability and biological activity of SB8 was maintained under all conditions: unopened vials 36 months after manufacture stored at $30 \pm 2{ }^{\circ} \mathrm{C}$ with $65 \pm 5 \%$ relative humidity for 1 month, opened vials stored at $5 \pm 3{ }^{\circ} \mathrm{C}$ for $72 \mathrm{~h}$ and diluted $(1.4$ or $16.5 \mathrm{mg} / \mathrm{ml}$ in $100 \mathrm{ml} 0.9 \% \mathrm{NaCl}$ polyolefin bags) stored for 45 days at $5 \pm 3{ }^{\circ} \mathrm{C}$ and then 3 days at $30 \pm 2{ }^{\circ} \mathrm{C}$

For all conditions, potential safety implication tests (particulates, aggregation) did not indicate concern

\section{INTRODUCTION}

Bevacizumab (Avastin ${ }^{\circledR}$, Genentech) is a humanized monoclonal antibody that binds vascular endothelial growth factor (VEGF) and prevents VEGF from interacting with its receptors on the surface of endothelial cells [1]. Bevacizumab was initially approved by the US Food and Drug Administration (FDA) in February 2004 and by the European Medicines Agency (EMA) in January 2005. The product SB8 is a proposed biosimilar to bevacizumab that is under review by the EMA and FDA agencies. On
June 25,2020 , a positive opinion recommending the granting of a marketing authorization was issued for SB8 (Aybintio) by the EMA's Committee for Medicinal Products for Human Use [2]. In a phase 3, randomized, double-blind study, patients with metastatic or recurrent nonsquamous non-small cell lung cancer had similar efficacy and safety with SB8, paclitaxel, and carboplatin or reference bevacizumab with the same chemotherapy regimen [3]. Comparable pharmacokinetic parameters and antidrug antibodies were noted for SB8 and its reference product.

Bevacizumab is available only as a liquid form in single-use vials of either $100 \mathrm{mg} / 4 \mathrm{ml}$ or $400 \mathrm{mg} / 16 \mathrm{ml}$ and must be diluted using aseptic technique with $0.9 \%$ sodium chloride prior to administration [1]. The unopened reference product should be stored at $2-8{ }^{\circ} \mathrm{C}$ in the original carton to protect it from light $[1,4]$. Diluted reference bevacizumab should be stored at $2-8{ }^{\circ} \mathrm{C}$ for up to $8 \mathrm{~h}$ according to the Avastin ${ }^{\circledR}$ prescribing information (PI) [1]. In contrast, chemical and physical in-use stability for dilutions of Avastin ${ }^{\circledR}$ have been demonstrated for 30 days at $2-8{ }^{\circ} \mathrm{C}$ plus an additional $48 \mathrm{~h}$ at $2-30{ }^{\circ} \mathrm{C}$ as stated in the Avastin ${ }^{\circledR}$ Summary of Product Characteristics (SmPC) [4]. Neither the Avastin $^{\circledR}$ PI nor the Avastin ${ }^{\circledR}$ SmPC mention storage or stability of unopened vials under ambient temperature conditions or of opened bevacizumab vials. In addition, in-use storage of dilutions of a bevacizumab biosimilar (Zirabev $^{\mathrm{TM}}$ ) for 35 days at $2-8{ }^{\circ} \mathrm{C}$ plus an additional $48 \mathrm{~h}$ at temperatures not exceeding $30^{\circ} \mathrm{C}$ is described in the SmPc [5].

Therapeutic effects of monoclonal antibodies depend upon their structural integrity [6]. Reuse of an open vial is cost-saving, especially for expensive monoclonal antibodies [7]. As temperature excursions occur and because drug wastage needs to be minimized, stability data for SB8 under various scenarios are warranted. Thus, evaluation of the stability of SB8 in various conditions is needed to help in the preparation and use of this biosimilar. Our study evaluated the stability of both unopened and opened SB8 vials and of diluted solutions from both physico-chemical and biological activity perspectives. 


\section{METHODS}

This article does not contain any studies with human participants or animals performed by any of the authors. All SB8 samples were prepared and experiments conducted aseptically in a biological safety cabinet.

\section{Sample Preparation}

\section{Stability of Opened/Pierced Vials}

Three batches of 100-mg vials and three batches of 400-mg vials were used. Each 400-mg vial contains $16 \mathrm{ml}$, and $15 \mathrm{ml}$ was withdrawn aseptically from each vial using a syringe with a $21 \mathrm{G}$ needle. Each 100-mg vial contains $4 \mathrm{ml}$, and $3 \mathrm{ml}$ was withdrawn aseptically from each vial using a syringe with a $21 \mathrm{G}$ needle. The vials were incubated at $5 \pm 3{ }^{\circ} \mathrm{C}$ under light protection (shielded chamber) for $72 \mathrm{~h}$. Test intervals were 0,24 and $72 \mathrm{~h}$.

\section{Stability of Unopened vials}

One batch of SB8 100-mg vials manufactured on January 20, 2017, and stored upright and lightprotected for 36 months at $5 \pm 3{ }^{\circ} \mathrm{C}$ was subsequently stored upright and light-protected for 1 month at $30 \pm 2{ }^{\circ} \mathrm{C}$ with $65 \pm 5 \%$ relative humidity beginning January 29,2020 . At each time point (day 0 , week 2 and month 1 ), vials were pulled from the shielded chamber for testing.

\section{Stability of Diluted SB8}

Three batches of $100 \mathrm{mg}$ unopened vials were stored at $30 \pm 2{ }^{\circ} \mathrm{C}$ with $65 \pm 5 \%$ relative humidity for $24 \mathrm{~h}$ in the shielded chamber before aseptically preparing the dilutions $(1.4 \mathrm{mg} / \mathrm{ml}$ and $16.5 \mathrm{mg} / \mathrm{ml})$. Infusion bags $(n=21)$ for each concentration were prepared (7 bags per batch). Bag 1 was used for day 0 sampling, bag 2 for day 7 sampling, bag 3 for day 14 sampling, bag 4 for day 21 sampling, bag 5 for day 35 sampling, bag 6 for day 37 sampling and bag 7 for both days 47 and 48 sampling. The bags were stored at $5 \pm 3{ }^{\circ} \mathrm{C}$ in the absence of light (shielded chamber) from days $0-45$ with the exception of bag 6 , which was stored at $30 \pm 2{ }^{\circ} \mathrm{C}$ with $65 \pm 5 \%$ relative humidity on days 36 and 37 . For bag 7 , on day 45 , storage was changed from $5 \pm 3{ }^{\circ} \mathrm{C}$ in the absence of light to $30 \pm 2{ }^{\circ} \mathrm{C}$ for 3 days.

The average overfill volume of $100 \mathrm{ml} 0.9 \%$ $\mathrm{NaCl}$ was determined and removed from each polyolefin bag (B. Braun). For the $1.4 \mathrm{mg} / \mathrm{ml}$ concentration, $5.6 \mathrm{ml}$ of $0.9 \% \mathrm{NaCl}$ was removed, and the same volume of SB8 was added from two unopened vials (each $100 \mathrm{mg}$ vial has $4 \mathrm{ml}$ ). For the $16.5 \mathrm{mg} / \mathrm{ml}$ concentration, $66 \mathrm{ml}$ of $0.9 \% \mathrm{NaCl}$ was removed and the same volume of SB8 was added from 17 unopened 100-mg vials. After SB8 addition, the bag was slowly inverted ten times. Sampling occurred on days $0,7,14,21,35,37,47$ and 48 . Only the purity and impurity tests were conducted on days 7, 21 and 47.

For the $1.4 \mathrm{mg} / \mathrm{ml}$ bags, a part of the sample was concentrated to $>10 \mathrm{mg} / \mathrm{ml}$ using Amicon Ultra centrifugal filters (30 K) (Merck Millipore) because the concentration was too dilute for the capillary electrophoresis-sodium dodecyl sulfate (CE-SDS), imaged capillary isoelectric focusing (icIEF), VEGF binding assay and VEGF neutralization assay.

\section{Biological and Physicochemical Analyses}

For both the unopened and opened vials, color was tested according to Ph. Eur. 2.2.2, clarity was tested according to Ph. Eur. 2.2.1, and visible particles were tested according to Ph. Eur. 2.9.20. For the diluted samples only, subvisible particulate assessment was by MFI, and the particle standard was analyzed with samples to confirm the system suitability. Dynamic light scattering (DLS) was used to determine submicronic aggregation only for the diluted samples, and the latex standard was analyzed with samples to confirm the system suitability.

The following tests were done for all three experiments: $\mathrm{pH}$ according to Ph. Eur. 2.2.3, protein concentration, VEGF neutralization assay, VEGF binding assay, and subvisible particulate $\geq 10 \mu \mathrm{m}$ and $\geq 25 \mu \mathrm{m}$ in size quantification via light obscuration with a HIAC $9703+$ and HRLD 400 instrument (Beckman Coulter, Inc.) per Ph. Eur. 2.9.19; particulates $\geq 2 \mu \mathrm{m}$ and $\geq 5 \mu \mathrm{m}$ were also counted for 
Table 1 Summary of tests

\begin{tabular}{|c|c|c|}
\hline Test & Method & Objective \\
\hline $\begin{array}{l}\text { Appearance } \\
\text { (color) }\end{array}$ & $\begin{array}{l}\text { Visual inspection using blue } \\
\text { standard (B1-B9) }\end{array}$ & Evaluation of color \\
\hline $\begin{array}{l}\text { Appearance } \\
\text { (clarity) }\end{array}$ & $\begin{array}{l}\text { Visual inspection using turbidity } \\
\text { standard (3 NTU-30 NTU) }\end{array}$ & Evaluation of clarity level \\
\hline $\begin{array}{l}\text { Appearance } \\
\text { (visible } \\
\text { particulates) }\end{array}$ & Visual inspection & Determination of visible particle number \\
\hline $\mathrm{pH}$ & $\mathrm{pH}$ measurement & Evaluation of $\mathrm{pH}$ \\
\hline $\begin{array}{l}\text { Protein } \\
\text { concentration }\end{array}$ & $\begin{array}{l}\mathrm{A}_{280} \text { measurement by UV-VIS } \\
\text { spectrophotometer }\end{array}$ & Determination of protein concentration \\
\hline SE-HPLC & $\begin{array}{l}\text { UV detection (wavelength, } \\
280 \mathrm{~nm} \text { ) }\end{array}$ & Determination of the total aggregates and monomer \\
\hline $\begin{array}{l}\text { CE-SDS (non- } \\
\text { reducing) }\end{array}$ & $\begin{array}{l}\text { UV radiation (wavelength, } \\
220 \mathrm{~nm} \text { ) }\end{array}$ & Determination of total purity and all impurities \\
\hline icIEF & Capillary imaging at $4^{\circ} \mathrm{C}$ & $\begin{array}{l}\text { Determination of the change in charge variance including acidic, } \\
\text { main and basic variants }\end{array}$ \\
\hline $\begin{array}{l}\text { VEGF } \\
\text { neutralization } \\
\text { assay }\end{array}$ & $\begin{array}{l}\text { VEGFR2-dependent reporter gene } \\
\text { system }\end{array}$ & Determination of the relative potency to the reference standard \\
\hline $\begin{array}{l}\text { VEGF binding } \\
\text { assay }\end{array}$ & ELISA & $\begin{array}{l}\text { Determination of the relative binding activity to the reference } \\
\text { standard }\end{array}$ \\
\hline $\begin{array}{l}\text { Subvisible } \\
\text { particulates }\end{array}$ & Light obscuration & $\begin{array}{l}\text { Determination of particulate matter in subvisible particles } \\
\text { (quantification of particles } \geq 2 \mu \mathrm{m}, \geq 5 \mu \mathrm{m}, \geq 10 \mu \mathrm{m} \\
\text { and } \geq 25 \mu \mathrm{m} \text { in size) }\end{array}$ \\
\hline $\begin{array}{l}\text { Subvisible } \\
\text { particulates }\end{array}$ & Microflow Imaging & $\begin{array}{l}\text { Determination of particulate matter in subvisible particles } \\
\text { (quantification of particles } \geq 2 \mu \mathrm{m}, \geq 5 \mu \mathrm{m}, \geq 10 \mu \mathrm{m} \\
\text { and } \geq 25 \mu \mathrm{m} \text { in size) }\end{array}$ \\
\hline $\begin{array}{l}\text { Submicronic } \\
\text { aggregation }\end{array}$ & Dynamic light scattering & $\begin{array}{l}\text { Evaluation of the comparability of submicron particle size } \\
(1-1000 \mathrm{~nm}) \text { : hydrodynamic diameter and polydispersity index }\end{array}$ \\
\hline
\end{tabular}

CE-SDS capillary electrophoresis-sodium dodecyl sulfate, ELISA enzyme-linked immunosorbent assay, icIEF imaged capillary isoelectric focusing, $N T U$ nephelometric turbidity units, SE-HPLC size exclusion high-performance liquid chromatography, $U V$ ultraviolet, $U V$-VIS ultraviolet visible, $V E G F$ vascular endothelial growth factor

the diluted samples. Purity and impurity tests consisted of SE-HPLC, icIEF and CE-SDS in nonreducing conditions with capillary gel electrophoresis. A summary of the tests conducted is provided in Table 1. Details of conductance of the purity and impurity tests as well as the biological function tests are provided below.

Forced degradation studies were conducted to assess the stability indicating nature of physicochemical and biological assays used. 
Specifically, SB8 was subjected to heat stress $\left(40 \pm 2{ }^{\circ} \mathrm{C}\right.$ with $75 \pm 5 \%$ relative humidity and stored for up to 3 months), oxidation (treatment with $0.01 \%$ final concentration of hydrogen peroxide and incubation at $5 \pm 3{ }^{\circ} \mathrm{C}$ for $24 \mathrm{~h})$, acid stress test ( $1 \mathrm{~N}$ hydrochloric acid treatment to $\mathrm{pH} 4.0$ and incubation at $25 \pm 2{ }^{\circ} \mathrm{C}$ for 3 days) and base stress test $(1 \mathrm{~N}$ sodium hydroxide treatment to $\mathrm{pH} 10.0$ and incubation at $25 \pm 2{ }^{\circ} \mathrm{C}$ for 3 days).

\section{Size Exclusion High-Performance Liquid Chromatography (SE-HPLC)}

Bevacizumab has irreversible and reversible aggregates, and the formation of reversible aggregate depends on $\mathrm{pH}$, concentration and temperature. Nondiluted SB8 samples were used to determine the total aggregate levels, which is the sum of irreversible and reversible aggregates. In contrast, diluted sample at $2 \mathrm{mg} / \mathrm{ml}$ was used for monomer level determination, so that reversible aggregates would dissociate. The dilution buffer used was $50 \mathrm{mM}$ sodium acetate, $\mathrm{pH}$ 5.0. As dilution was not needed for the low concentration $(1.4 \mathrm{mg} / \mathrm{ml})$, the percentage total aggregate and percentage monomer were determined by one analysis.

For SE-HPLC, samples were injected onto a TSK gel G3000SW $W_{\mathrm{XL}}$ column $(5 \mu \mathrm{m} /$ $7.8 \mathrm{~mm} \times 300 \mathrm{~mm}$; TOSOHAAS) with a flow rate of $0.5 \mathrm{ml} / \mathrm{min}$ and a mobile phase that consisted of $200 \mathrm{mM}$ potassium phosphate, $250 \mathrm{mM}$ potassium chloride, $\mathrm{pH}$ 6.23. Detection occurred at $280 \mathrm{~nm}$.

\section{Imaged Capillary Isoelectric Focusing (icIEF)}

An imaged capillary isoelectric focusing system (iCE3, Protein Simple) was used for determination of the distribution of charged species. Samples were mixed with the carrier ampholytes, injected into a transparent column (capillary), retained in a microscope-slide cartridge and separated by the system using free-solution isoelectric focusing. Specifically, the samples were introduced onto the fluorocarbon-coated capillary $(100 \mu \mathrm{m} / 50 \mathrm{~mm}$, Protein Simple), a pH gradient was created inside the capillary by small ampholyte molecules, and charged proteins electrophoretically moved to the point where the $\mathrm{pH}$ of the capillary was equal to the isoelectric point of the protein. The movement was recorded by a charge-coupled device camera.

\section{Capillary Electrophoresis-Sodium Dodecyl Sulfate (CE-SDS)}

A high-performance capillary electrophoresis system (PA 800 Plus Pharmaceutical Analysis System; Beckman Coulter, Inc.) was used for CESDS analyses. Alkylated, non-reduced SB8 in the presence of sodium dodecyl sulfate with the addition of a 10-kDa internal standard was used. Each sample was electrokinetically introduced onto a capillary $(50 \mu \mathrm{m} / 30.2 \mathrm{~cm}$; Beckman Coulter, Inc.). UV radiation (wavelength, $220 \mathrm{~nm}$ ) was passed through the capillary window aperture $(100 \times 200 \mu \mathrm{m}$; Beckman Coulter, Inc.) and was detected by the PA800 Plus.

\section{VEGF Binding Assay}

An ELISA plate had VEGF-A 165 adsorbed, nonspecific binding to the plate surface blocked by bovine serum albumin-containing buffer, serially diluted SB8 added to bind to VEGF-A 165, an HRP-conjugated anti-hIgG (Fc specific) antibody added to bind to bound SB8 and an appropriate chromogenic substrate added to produce a colored product by peroxidase. The test plate was then read on a spectrophotometer at $450 \mathrm{~nm}$. The optical density, which was directly proportional to the SB8 concentration, was yielded, and the relative VEGF-A 165 binding activity of SB8 was determined by analyzing a four-parameter curve plotted from data in the parallel line analysis software.

\section{VEGF Neutralization Assay}

A VEGFR2-dependent reporter gene system was used to determine the neutralization potency of VEGF-A 165 by SB8. Specifically, the HEK293NFAT-VEGFR2-Luc cell line contained the nuclear factor of activated T-cell binding sequence in the promoter region of the luciferase reporter gene. Bound VEGF to VEGFR2 led to VEGFR2-dependent signal pathway activation and the expression of the luciferase reporter gene. Thus, the neutralization potency of VEGF-A 165 by SB8 was calculated based on 
dose-dependent changes in luminescence levels that corresponded to the amount of luciferase in the cell line.

\section{RESULTS}

For both the ambient temperature stability (unopened vial) experiment and for in-use stability (opened vial and diluted solution) experiments, all test results met the acceptance criteria. For the opened vials stored at $5 \pm 3{ }^{\circ} \mathrm{C}$ for $72 \mathrm{~h}$, no notable differences between the 100-mg and $400-\mathrm{mg}$ vials were noted. For the dilutions, no notable differences between the $1.4 \mathrm{mg} / \mathrm{ml}$ and $16.5 \mathrm{mg} / \mathrm{ml}$ concentrations were noted.

\section{Appearance and $\mathrm{pH}$}

For either unopened SB8 stored at $30 \pm 2{ }^{\circ} \mathrm{C}$ with $65 \pm 5 \%$ relative humidity for 1 month or opened SB8 stored at $5 \pm 3{ }^{\circ} \mathrm{C}$ for $72 \mathrm{~h}$, no precipitates or particulate matter was detected by visual inspection, and no change in clarity was noted. The only change in color was from B6 to B5, which was noted for all three 100-mg vials at both the 24-h and 72-h assessment of the stability for opened vials. This change was well within the acceptance criteria. Minimal $( \pm 0.2$ $\mathrm{pH}$ units) variation in $\mathrm{pH}$ was observed over time including for diluted SB8.

\section{Quantity Measurement}

For both the unopened and opened SB8 vials, the expected concentration was $25 \mathrm{mg} / \mathrm{ml}$ and was measured to be between 24.2 and $25.1 \mathrm{mg} /$ $\mathrm{ml}$. The measured protein concentration was the expected concentration for the target diluted concentration of $1.4 \mathrm{mg} / \mathrm{ml}$ and ranged from 15.7 to $16.7 \mathrm{mg} / \mathrm{ml}$ for the target of $16.5 \mathrm{mg} / \mathrm{ml}$. The target high concentration was maintained within assay variation.

\section{Purity and Impurity Analyses}

No major change was noted in the proportion of percentage for the total aggregate or percentage for the monomer, in the total purity or in the
\%Acidic, \%Main and \%Basic profiles of the protein for unopened SB8 stored at $30 \pm 2{ }^{\circ} \mathrm{C}$ with $65 \pm 5 \%$ relative humidity for 1 month (Fig. 1a-f), opened SB8 stored at $5 \pm 3{ }^{\circ} \mathrm{C}$ for $72 \mathrm{~h}$ (Fig. 2a-f) or unopened SB8 stored for $30^{\circ} \mathrm{C}$ for $24 \mathrm{~h}$, which was then diluted at either a low or high concentration and stored for 48 days (Fig. 3a-f). Example chromatograms and electropherograms for diluted SB8 on days 0 and 48 are shown in Fig. 4 (total aggregate), Fig. 5 (monomer), Fig. 6 (impurities) and Fig. 7 (relative percentages of acidic, main, and basic isoforms). Concerning impurities $\geq 1.0 \%$, only the two heavy one-light-chain (2H1L) impurity was present in all samples and at all time points including baseline from the opened vial and from the dilutions; the percentage of $2 \mathrm{H} 1 \mathrm{~L}$ ranged between 1.2 and $1.9 \%$. Similar results for the 2H1L impurity were noted for the unopened vial, but high molecular weight 1 (HMW1) was also noted at $1.2 \%$. No major change in molecular weight variants over time were noted for opened or diluted SB8. Although changes in molecular weight variant and charge distribution were noted in the unopened SB8, all results were within the acceptance criteria.

\section{Biological Activity Assays}

No substantial changes in either the VEGF neutralization assay or the VEGF binding assay were noted for all tested conditions at all time points (Figs. $8 \mathrm{a}-\mathrm{c}, 9 \mathrm{a}-\mathrm{c}$ ).

\section{Potential Safety Implication Tests}

No meaningful trend was noted for particulates $\geq 10 \mu \mathrm{m}$ or $\geq 25 \mu \mathrm{m}$ over time for unopened SB8, opened SB8 or diluted solutions. For both the low- and high-diluted SB8 concentrations, no appreciable changes in the average number of subvisible particulates sized $\geq 2 \mu \mathrm{m}$ or $\geq 5 \mu \mathrm{m}$ were noted (data not shown). For the low concentration samples of diluted solution, particulates $\geq 2 \mu \mathrm{m}$ ranged from 143 to 4416 and particulates $\geq 5 \mu \mathrm{m}$ ranged from 23 to 892 . For the high-concentration samples, particulates $\geq 2 \mu \mathrm{m}$ ranged from 1624 to 15,048 and particulates $\geq 5 \mu \mathrm{m}$ ranged from 94 to 10,261 . 


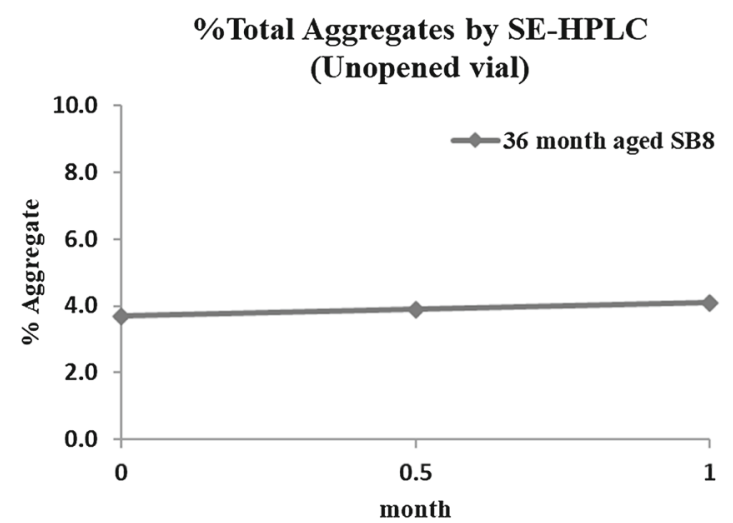

a Percentage total aggregates by size exclusion high performance liquid chromatography.

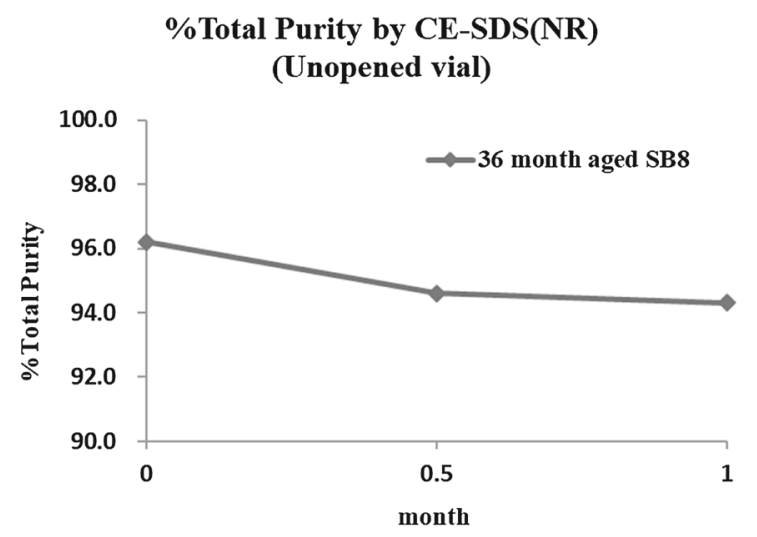

c Percentage total purity by capillary electrophoresissodium dodecyl sulfate (nonreducing).

\%Main by icIEF

(Unopened vial)

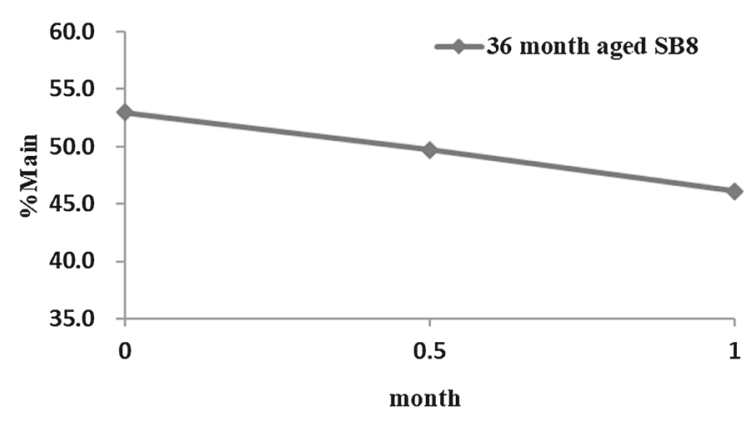

e Percentage Main by imaged capillary isoelectric focusing.
\%Monomer by SE-HPLC

(Unopened vial)

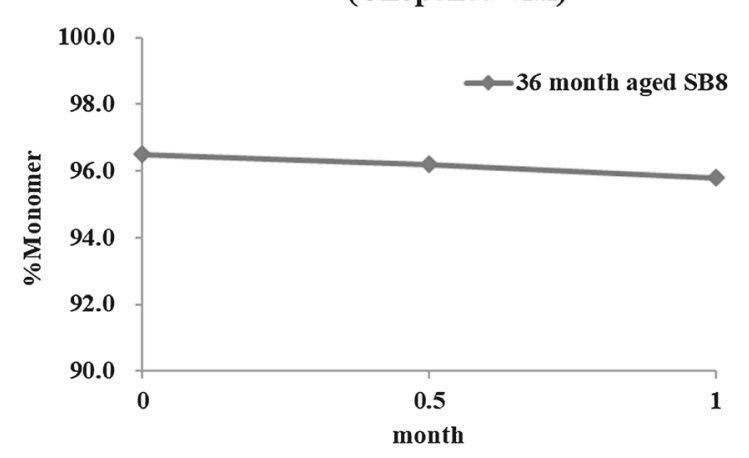

b Percentage monomer by size exclusion high performance liquid chromatography.

\%Acidic by icIEF

(Unopened vial)

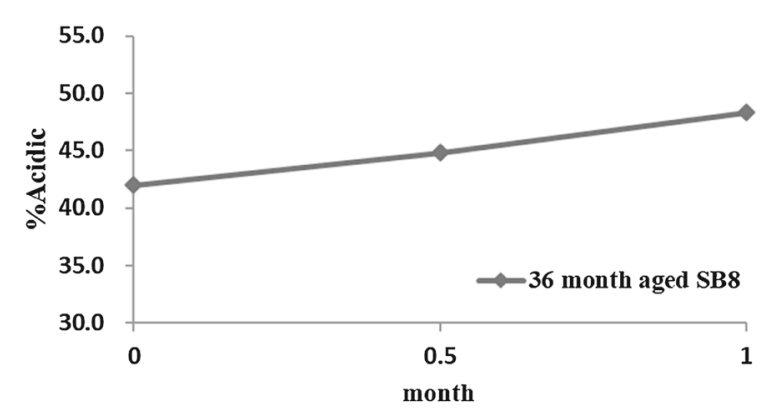

d Percentage Acidic by imaged capillary isoelectric focusing.

\%Basic by icIEF

(Unopened vial)

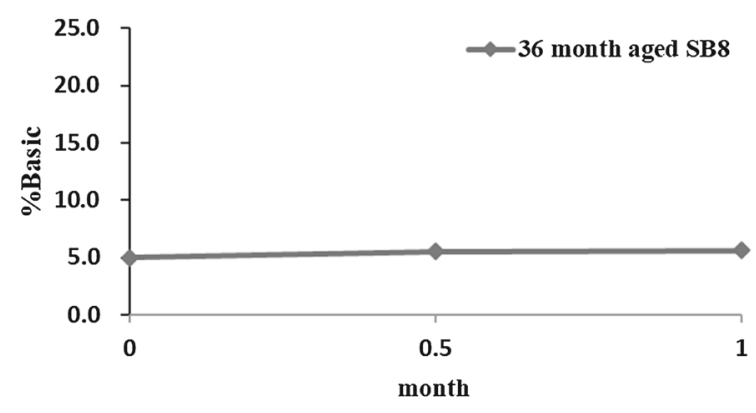

f Percentage Basic by imaged capillary isoelectric focusing.

Fig. 1 Stability trends for unopened SB8 stored at $30 \pm 2{ }^{\circ} \mathrm{C}$ and $65 \pm 5 \%$ relative humidity in absence of light 


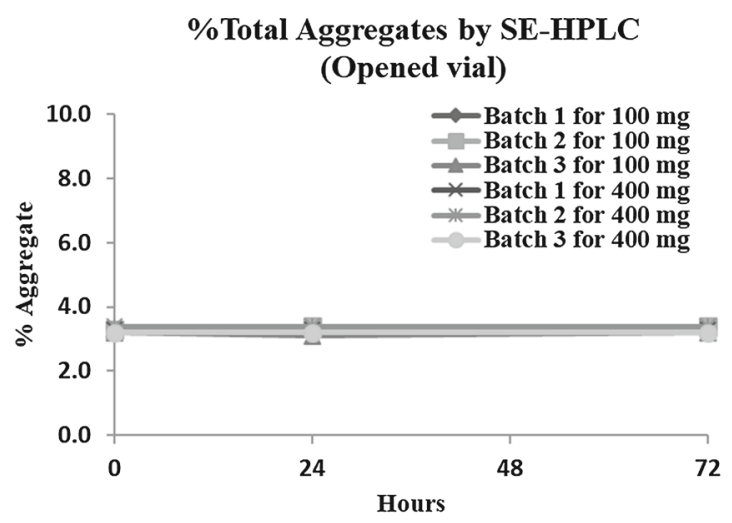

a Percentage total aggregates by size exclusion high performance liquid chromatography.

\% Total Purity by CE-SDS(NR)

(Opened vial)

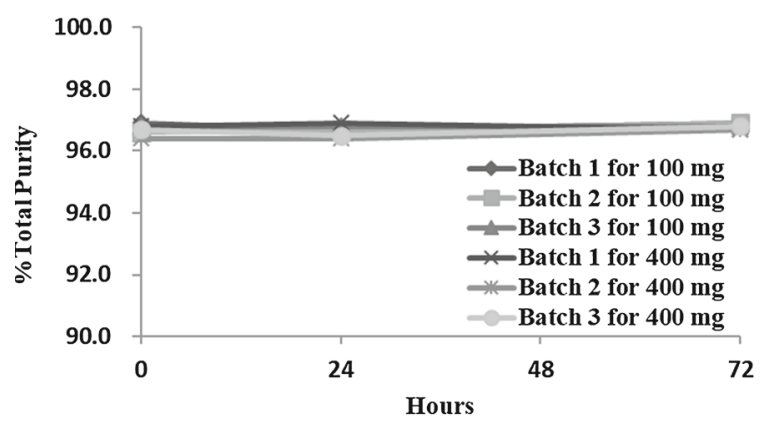

c Percentage total purity by capillary electrophoresissodium dodecyl sulfate (nonreducing).

\%Main by icIEF

(Opened vial)

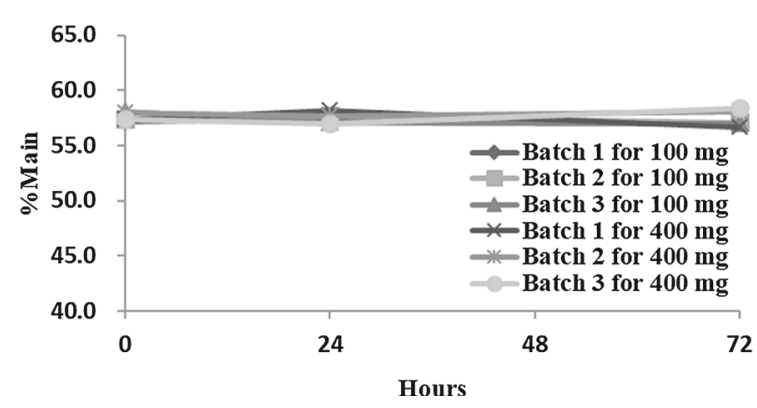

e Percentage Main by imaged capillary isoelectric focusing.
\%Monomer by SE-HPLC

(Opened vial)

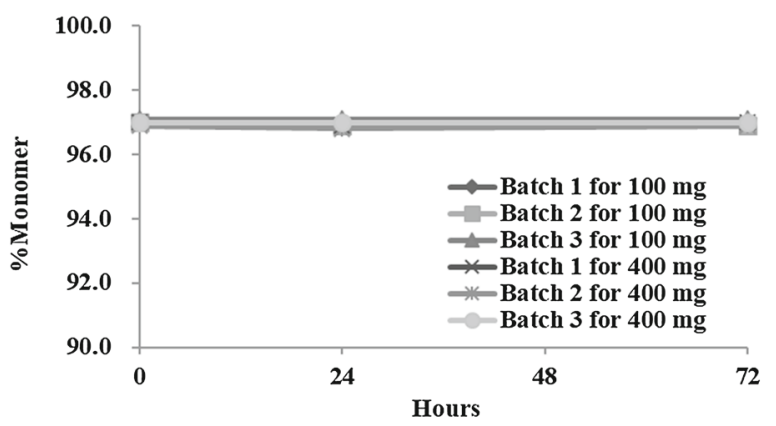

b Percentage monomer by size exclusion high performance liquid chromatography.

\%Acidic by icIEF

(Opened vial)

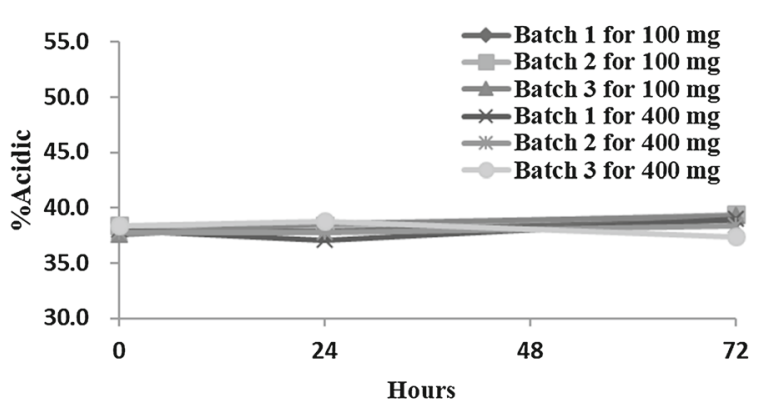

d Percentage Acidic by imaged capillary isoelectric focusing.

\%Basic by icIEF

(Opened vial)

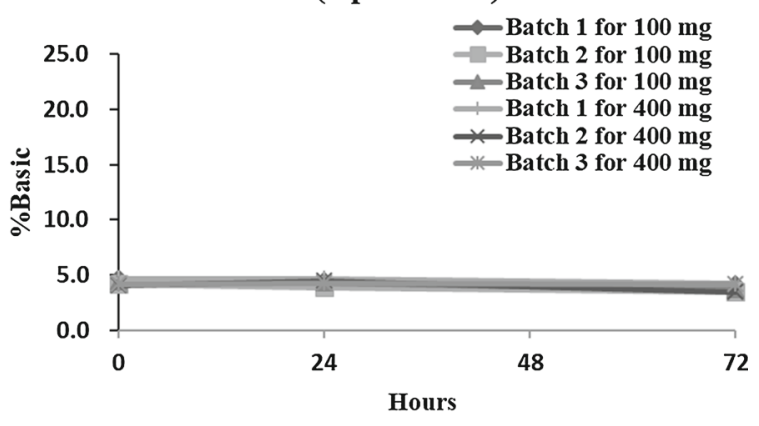

f Percentage Basic by imaged capillary isoelectric focusing.

Fig. 2 Stability trends for opened (leftover/pierced) SB8 stored at $5 \pm 3{ }^{\circ} \mathrm{C}$ in absence of light 


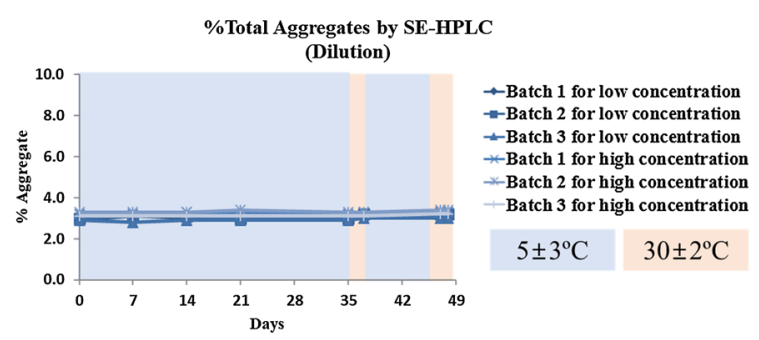

a Percentage total aggregates by size exclusion high performance liquid chromatography.

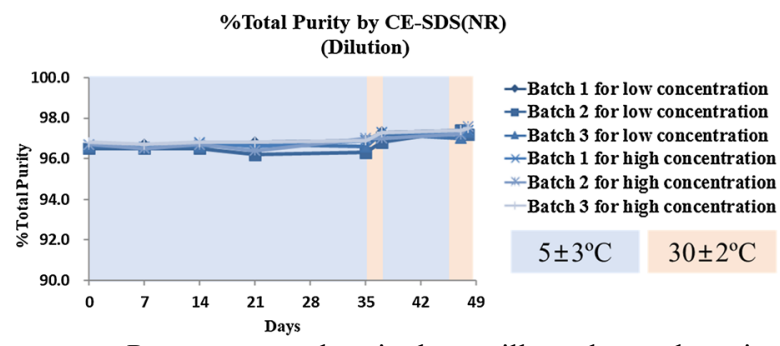

c Percentage total purity by capillary electrophoresissodium dodecyl sulfate (nonreducing).

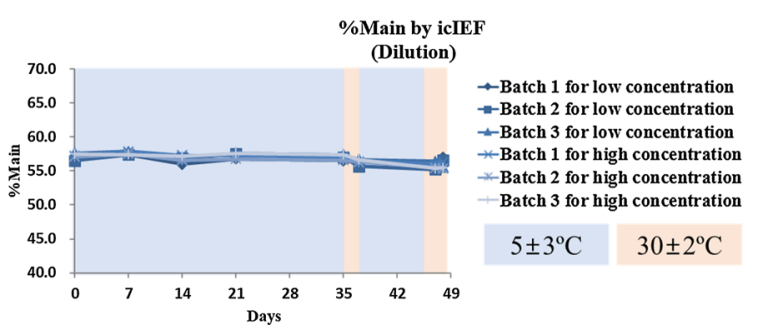

e Percentage Main by imaged capillary isoelectric focusing.

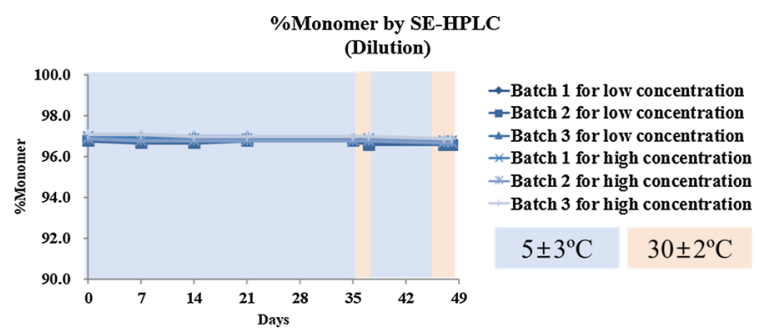

b Percentage monomer by size exclusion high performance liquid chromatography.

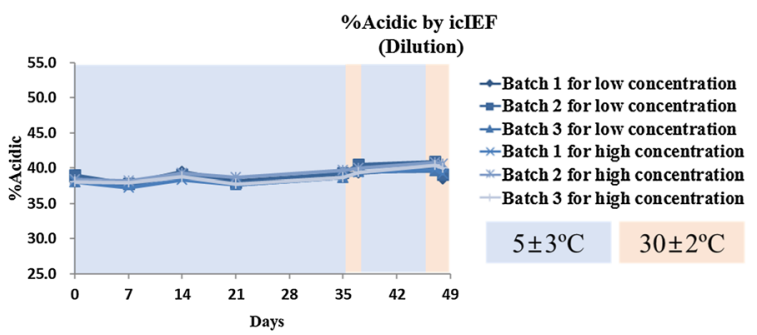

d Percentage Acidic by imaged capillary isoelectric focusing.

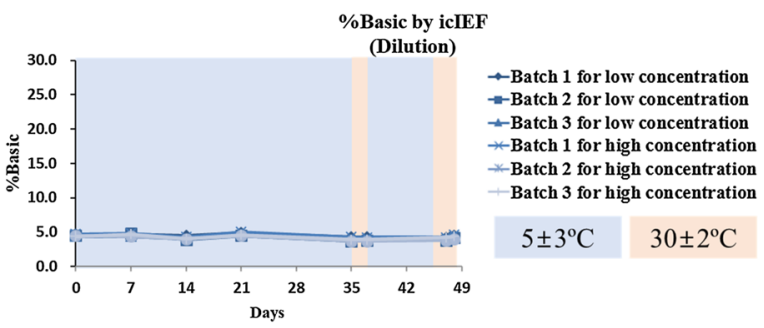

f Percentage Basic by imaged capillary isoelectric focusing.

Fig. 3 Stability trends for diluted SB8 stored at $5 \pm 3{ }^{\circ} \mathrm{C}$ for 45 days and at $30 \pm 2{ }^{\circ} \mathrm{C}$ for the following 3 days in absence of light

No trend increase in either the hydrodynamic diameter (Fig. 10a) or the polydispersity index (Fig. 10b) was noted as assessed by DLS. No populations of high hydrodynamic diameter were present, especially between 100 and $1000 \mathrm{~nm}$.

Under oxidation, the \%oxidation of methionine (Met) 258 increased, but no correlation between oxidation of methionine residue and potency by VEGF neutralization assay was found. The \%total purity, \%monomer, \%total aggregate, \%main peak, \%acidic and \%potency by VEGF neutralization were relatively unchanged. Under heat stress, reductions in \%total purity, \%monomer, \%relative potency by VEGF neutralization, \%relative binding activity by
VEGF and \%main occurred, whereas increases in $\%$ total aggregate and \%acidic were noted. Under high $\mathrm{pH}$ stress, \%monomer and \%total purity were reduced and \%total aggregate and \%acidic were increased; no change was noted in \%potency by VEGF neutralization. Under low $\mathrm{pH}$ stress, \%monomer was reduced and \%total aggregate was increased; no change was noted in \%potency by VEGF neutralization.

\section{DISCUSSION}

Guidance for in-use stability includes the use of a minimum of two batches, application of tests to the product that presents the greatest 


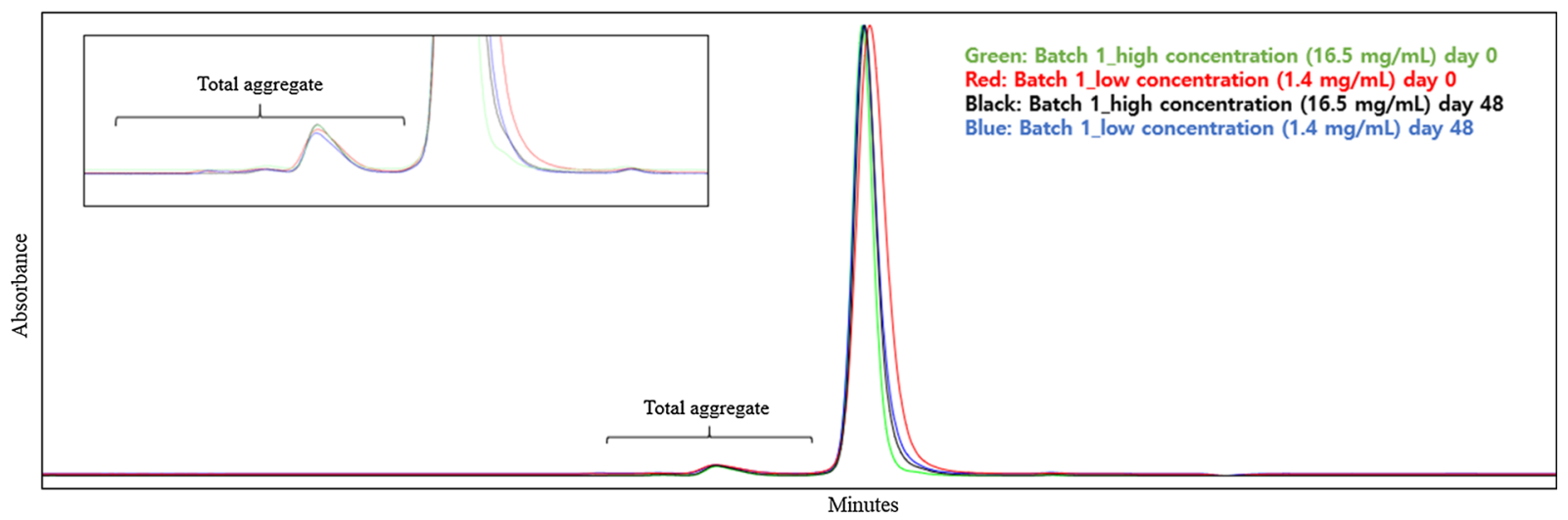

Fig. 4 Chromatogram for total aggregate per size exclusion high-performance liquid chromatography for diluted SB8 at day 0 and day 48 at $5 \pm 3{ }^{\circ} \mathrm{C}$ for 45 days and at $30 \pm 2{ }^{\circ} \mathrm{C}$ for the following 3 days in absence of light.
Green line: SB8 batch $1(16.5 \mathrm{mg} / \mathrm{ml})$ on day 0 , red line: SB8 batch $1(1.4 \mathrm{mg} / \mathrm{ml})$ on day 0, black line: SB8 batch 1 $(16.5 \mathrm{mg} / \mathrm{ml})$ on day 48 , blue line: SB8 batch $1(1.4 \mathrm{mg} /$ $\mathrm{ml})$ on day 48

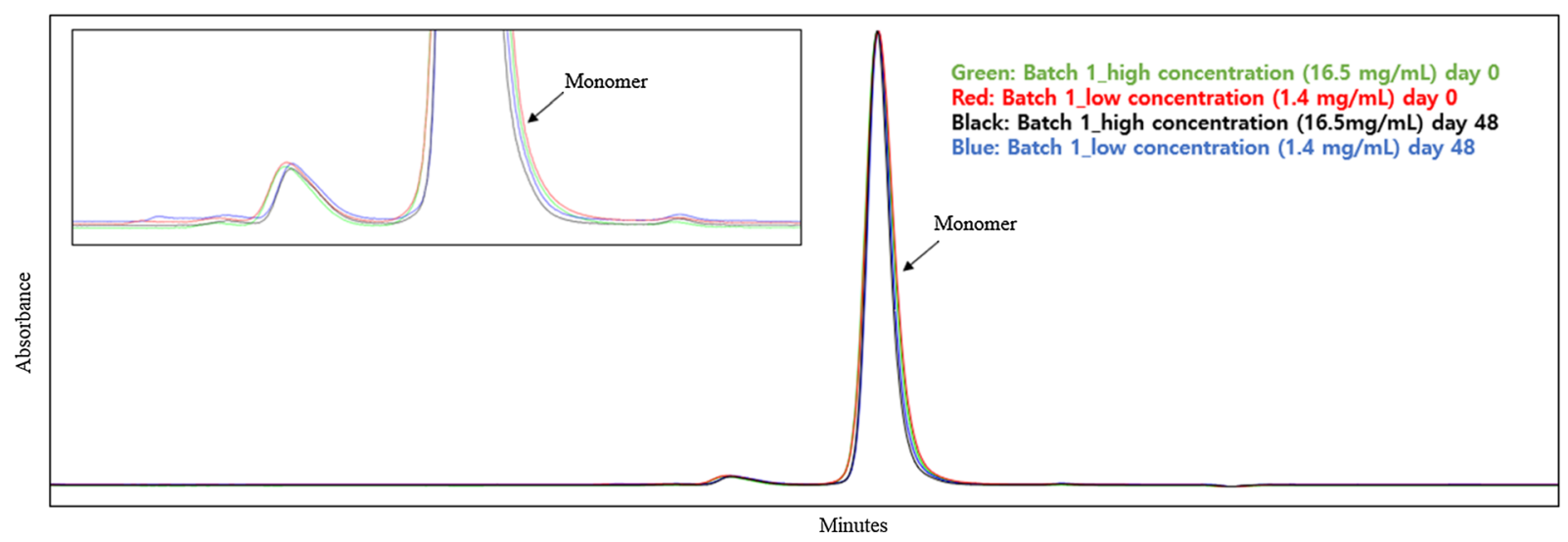

Fig. 5 Chromatogram for monomer per size-exclusion high-performance liquid chromatography for diluted SB8 at day 0 and day 48 at $5 \pm 3{ }^{\circ} \mathrm{C}$ for 45 days and at $30 \pm 2{ }^{\circ} \mathrm{C}$ for the following 3 days in absence of light.

susceptibility to change, simulation of product use in practice and determination of the appropriate physical, chemical and microbial properties of the product [8]. The dilutions were prepared as they would be in clinical practice, clinically low- and high-diluted concentrations were utilized, three batches for both opened vials and diluted product were used, and the physical and chemical properties of SB8 susceptible to change were monitored.

In addition to in-use stability guidance, protocol requirements exist for the diluted
Green line: SB8 batch $1(16.5 \mathrm{mg} / \mathrm{ml})$ on day 0, red line: SB8 batch $1(1.4 \mathrm{mg} / \mathrm{ml})$ on day 0, black line: SB8 batch 1 $(16.5 \mathrm{mg} / \mathrm{ml})$ on day 48 , blue line: SB8 batch $1(1.4 \mathrm{mg} /$ $\mathrm{ml})$ on day 48

solution stability per the United Kingdom's National Health Service (NHS) guidance: storage condition, storage period, sampling strategy, diluent, batch, containers, concentrations and sampling number. Consistent with NHS protocol requirements were the diluent as per the SmPC, three independent batches, a nonpolyvinylchloride container, and a low and high clinically significant drug concentration. In fact, according to the Avastin ${ }^{\circledR}$ SmPC, the concentration of the final bevacizumab solution should be kept within the range of 1.4 to 


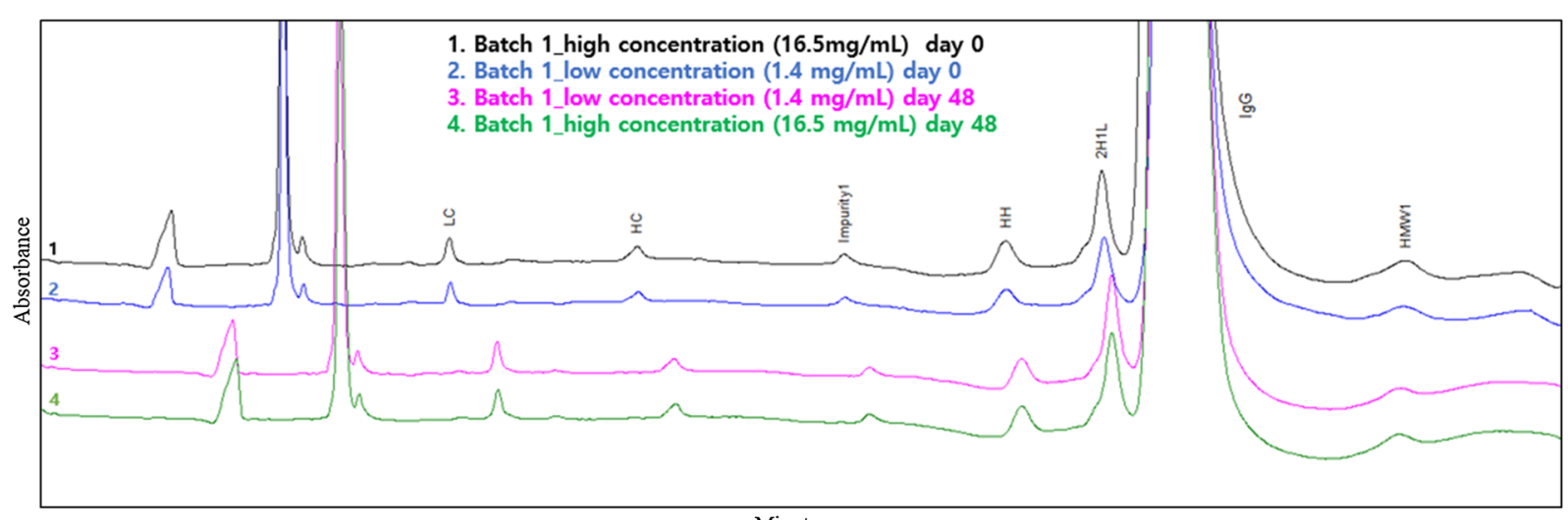

Minutes

Fig. 6 Electropherogram for capillary electrophoresis sodium dodecyl sulfate (non-reducing) for diluted SB8 at day 0 and day 48 at $5 \pm 3{ }^{\circ} \mathrm{C}$ for 45 days and at $30 \pm 2{ }^{\circ} \mathrm{C}$ for the following 3 days in absence of light. Black line: SB8 batch $1(16.5 \mathrm{mg} / \mathrm{ml})$ on day 0, blue line:
SB8 batch $1(1.4 \mathrm{mg} / \mathrm{ml})$ on day 0 , pink line: SB8 batch 1 $(1.4 \mathrm{mg} / \mathrm{ml})$ on day 48 , green line: SB8 batch $1(16.5 \mathrm{mg} /$ $\mathrm{ml}$ ) on day $482 H I L$ two heavy one light chain, $H C$ heavy chain, $H H$ two heavy chain, HMW high molecular weight, IgG immunoglobulin G, $L C$ light chain

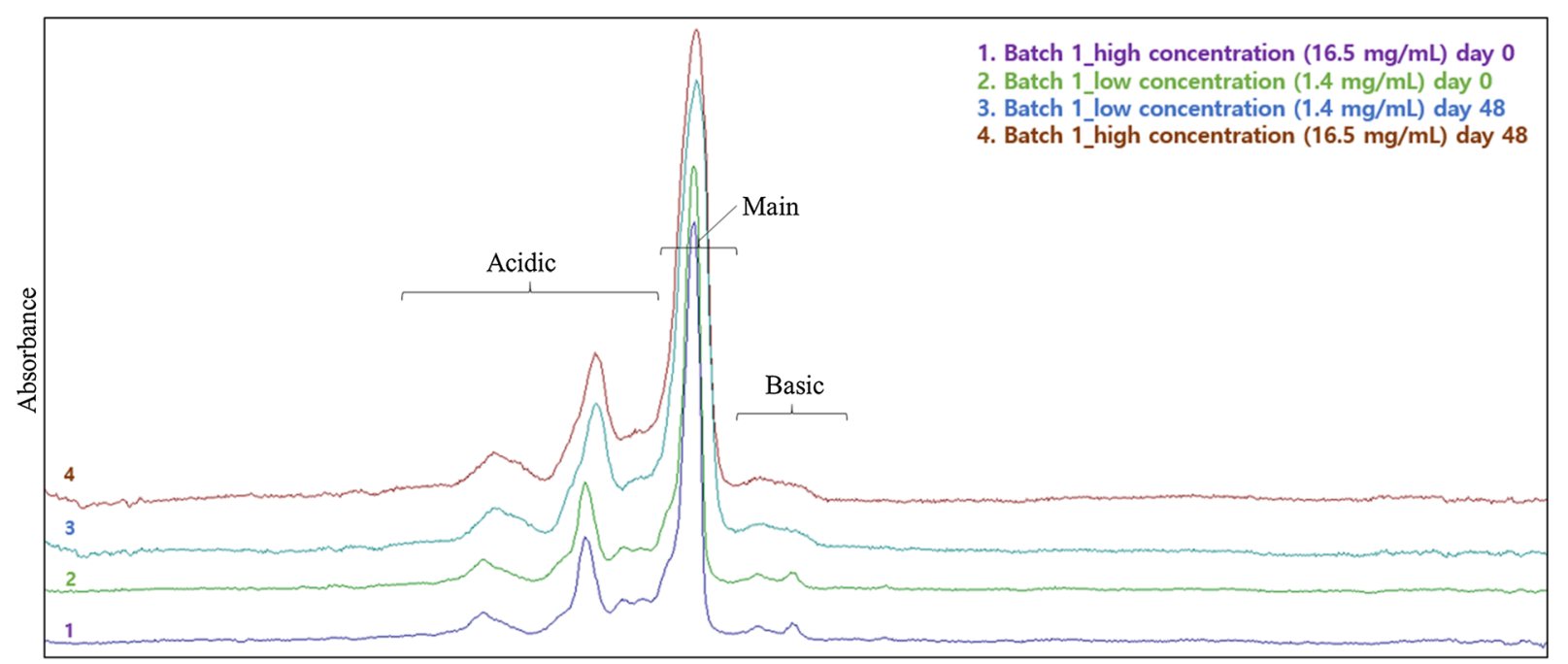

Isoelectric Point

Fig. 7 Electropherogram for imaged capillary isoelectric focusing for diluted SB8 at day 0 and day 48 at $5 \pm 3{ }^{\circ} \mathrm{C}$ for 45 days and at $30 \pm 2{ }^{\circ} \mathrm{C}$ for the following 3 days in absence of light. Purple line: SB8 batch $1(16.5 \mathrm{mg} / \mathrm{ml})$ on

$16.5 \mathrm{mg} / \mathrm{ml}$. Therefore, the two acceptable extremes were used in our experiment. Also, the use of polyolefin bags was appropriate, as no incompatibilities between bevacizumab and polyolefin containers or infusion sets were observed [4]. day 0, green line: SB8 batch $1(1.4 \mathrm{mg} / \mathrm{ml})$ on day 0 , blue line: SB8 batch $1(1.4 \mathrm{mg} / \mathrm{ml})$ on day 48 , brown line: SB8 batch $1(16.5 \mathrm{mg} / \mathrm{ml})$ on day 48

Variances in the storage condition, storage period, sampling strategy and sampling number existed. Per NHS guidance, the storage condition was refrigerated $\left(5 \pm 3^{\circ} \mathrm{C}\right)$ in the absence of light, but the room temperature storage condition was $30 \pm 2{ }^{\circ} \mathrm{C}$ instead of $25 \pm 2{ }^{\circ} \mathrm{C}$ to account for the possibility of cold chain 


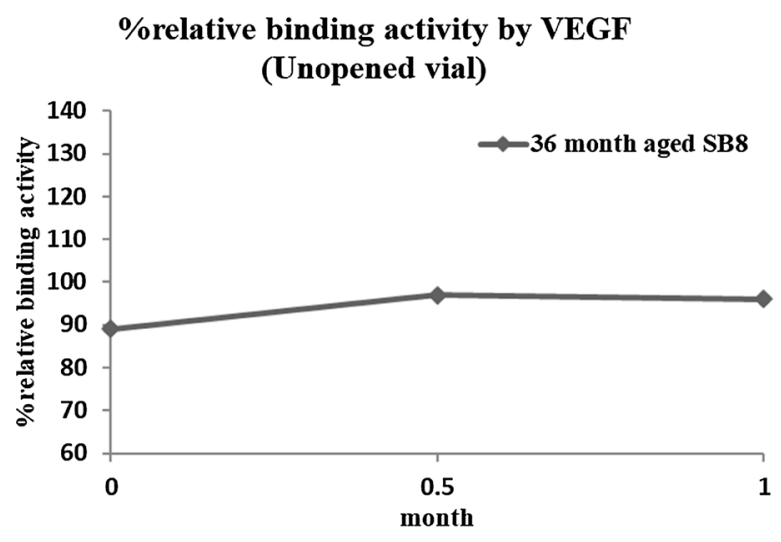

a unopened SB8 stored at $30 \pm 2^{\circ} \mathrm{C}$ and $65 \pm 5 \%$ relative humidity in absence of light.
\% relative binding activity by VEGF (Opened vial)

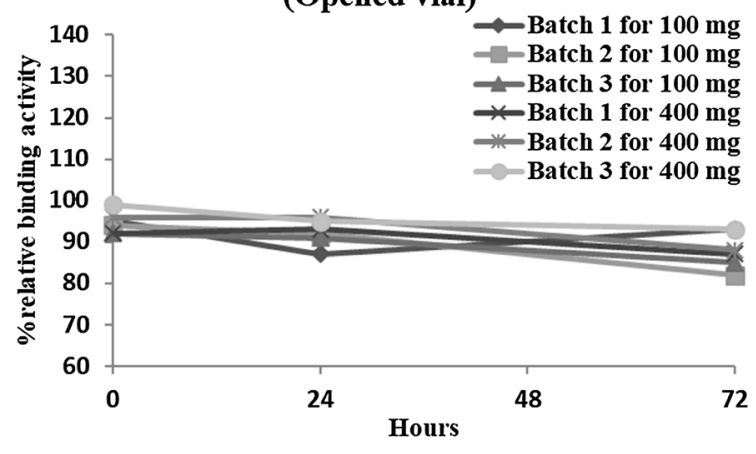

b opened (left-over/pierced) SB8 stored at $5 \pm 3^{\circ} \mathrm{C}$ in absence of light.

\%relative binding activity by VEGF

(Dilution)

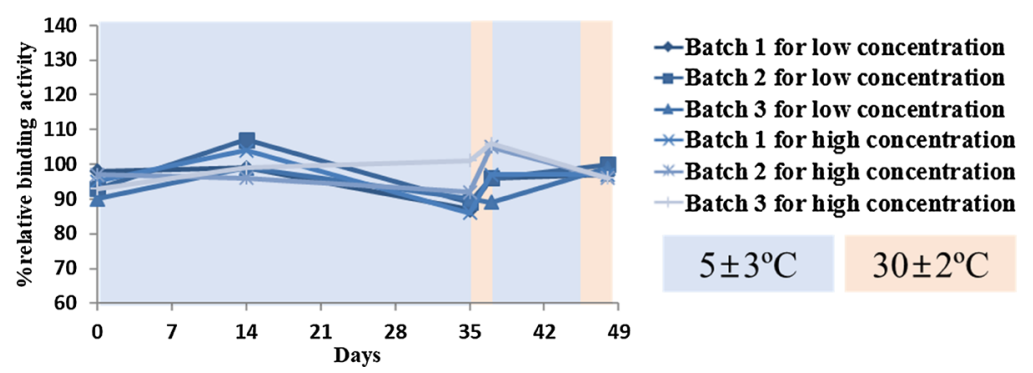

c diluted SB8 stored at $5 \pm 3^{\circ} \mathrm{C}$ for 45 days and at $30 \pm 2{ }^{\circ} \mathrm{C}$ for the following 3 days in absence of light.

Fig. 8 Percentage relative binding activity by VEGF. $V E G F$ vascular endothelial growth factor

breakage. As $30^{\circ} \mathrm{C}$ is higher than $25^{\circ} \mathrm{C}$, stability demonstrated at $30^{\circ} \mathrm{C}$ was taken as evidence of stability at $25^{\circ} \mathrm{C}$. The NHS protocol requirement is a 2-day to 3-month storage period with an assigned shelf life ideally not exceeding 80\% of the final time point that demonstrates adequate stability. As the study design is compliant with NHS (UK) guidance, our data can be used to support the extended shelf-life of SB8 in the UK. In our study, the final time point for $5 \pm 3{ }^{\circ} \mathrm{C}$ was 45 days, so the shelf-life of 35 days when stored at $5 \pm 3{ }^{\circ} \mathrm{C}$ can be proposed when applying NHS standards. The shelf-life of 37 days when stored at $5 \pm 3^{\circ} \mathrm{C}$ and then for at $30 \pm 2{ }^{\circ} \mathrm{C}$ for up to $48 \mathrm{~h}$ also met the criteria and can be proposed when following NHS guidance, as the final time point was 48 days.
For the sampling strategy, the NHS protocol requirement for studies $<6$ months in duration is at least four sampling points in addition to the baseline. The five time points were days 0 , $14,35,37$ and 48 . However, days 37 and 48 included storage at $30 \pm 2{ }^{\circ} \mathrm{C}$ for 2 or 3 days, respectively. These two time points were considered adequate for stability at $5 \pm 3^{\circ} \mathrm{C}$ because $30 \pm 2{ }^{\circ} \mathrm{C}$ is a harsher storage condition. NHS guidance requirements state the need for triplicate sampling for sampling number at each time point. However, sample homogeneity with SB8 was demonstrated, including consistent protein concentrations after use of our protocol that clearly described the mixing steps to prepare both a $1.4 \mathrm{mg} / \mathrm{ml}$ and a $16.4 \mathrm{mg} / \mathrm{ml}$ solution. Thus, a single preparation was 


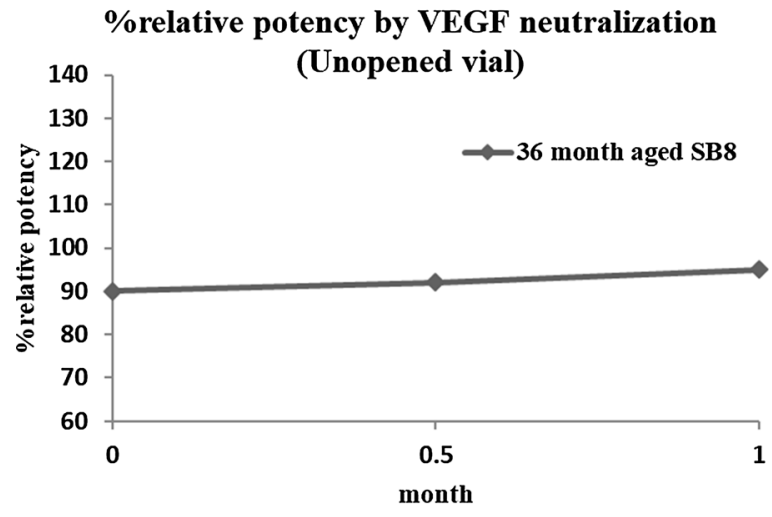

a unopened $\mathrm{SB} 8$ stored at $30 \pm 2^{\circ} \mathrm{C}$ and $65 \pm 5 \%$ relative humidity in absence of light.

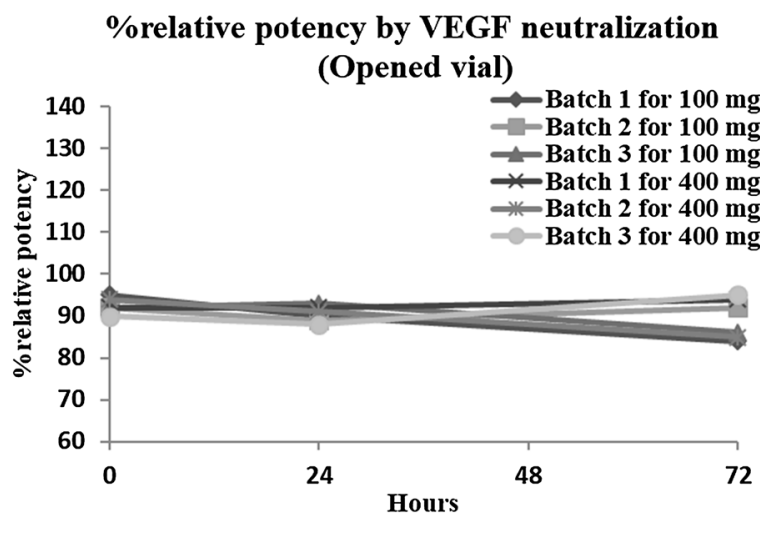

b opened (left-over/pierced) SB8 stored at $5 \pm 3^{\circ} \mathrm{C}$ in absence of light.

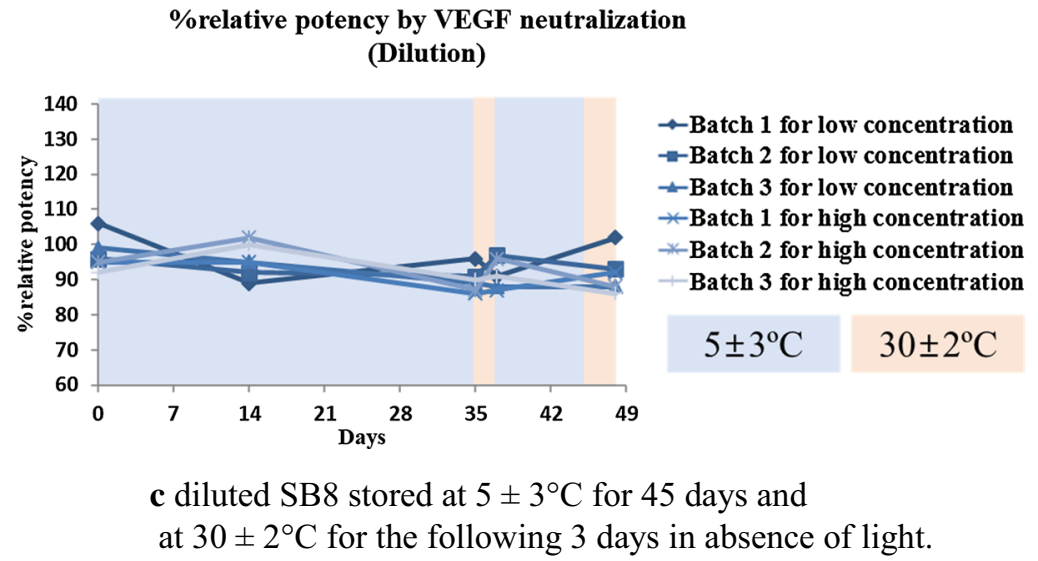

Fig. 9 Percentage relative potency by VEGF neutralization. $V E G F$ vascular endothelial growth factor

considered adequate. Regarding sampling number, the number of replicate testings varies based on each test's standard operating procedure (SOP). All of the utilized methods were validated according to the ICH Q2(R1) guideline for validation of analytical procedures [9]. The number of replicates used was in line with the SOP of each test measure and thus was considered adequate to obtain reliable stability data.

The stability-indicating profile of a product cannot be provided by a single stability-indicating assay or parameter [10]. Several orthogonal and complementary methods were used to assess physico-chemical stability, and a combination of techniques is required to give robust information $[11,12]$. For example, although SE-
HPLC detects molecular weight variants, use of CE-SDS achieves a higher resolution separation of low-molecular-weight variants from antibodies such as bevacizumab [13]. Furthermore, forced degradation study results supported the stability-indicating nature of the tests used.

For all studied conditions (opened vial at $2-8{ }^{\circ} \mathrm{C}$ for $72 \mathrm{~h}$, unopened vial at $30 \pm 2{ }^{\circ} \mathrm{C}$ with $65 \pm 5 \%$ relative humidity for 1 month and diluted at $5 \pm 3{ }^{\circ} \mathrm{C}$ for 45 days and $30 \pm 2{ }^{\circ} \mathrm{C}$ with $65 \pm 5 \%$ relative humidity for $72 \mathrm{~h}$ ), no noteworthy changes were observed in any of the tested quality attributes. No signs of physical instability relative to freshly prepared samples were noted, including no noteworthy increase of either high or low molecular weight or change in charge isoforms, which indicates 


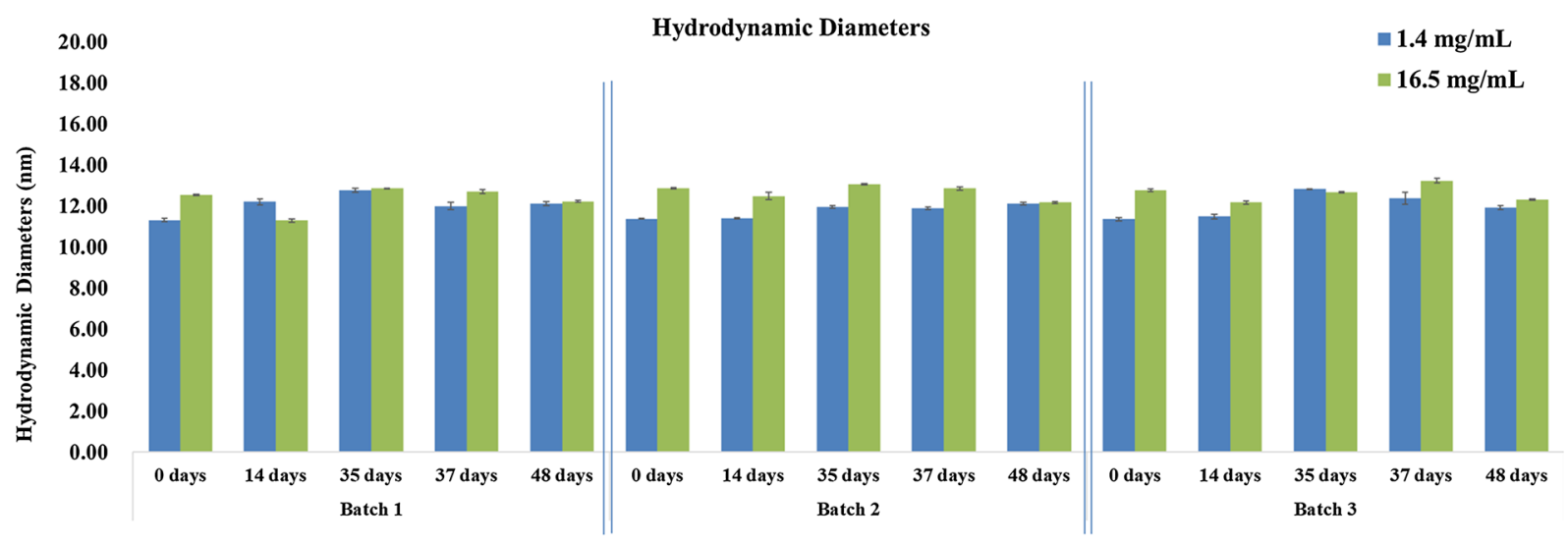

a Hydrodynamic diameters

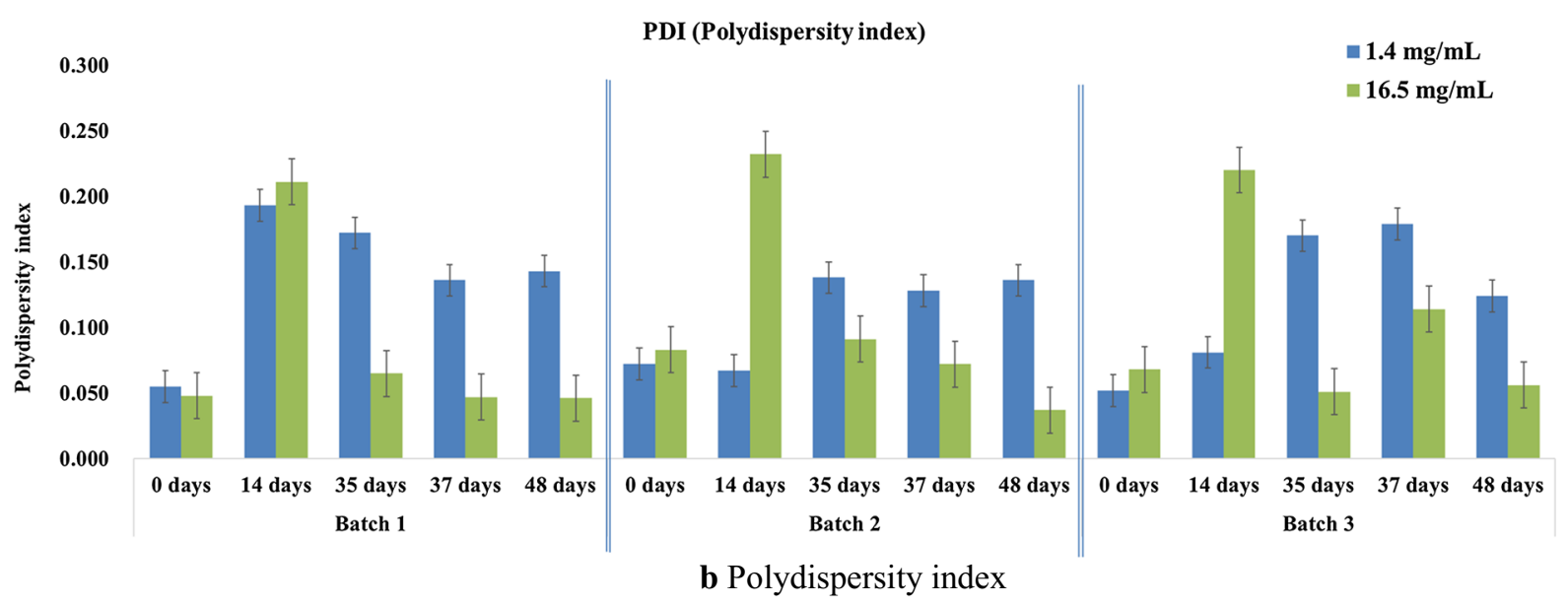

Fig. 10 Trends in submicronic aggregation assessed by dynamic light scattering for diluted solutions at $5 \pm 3{ }^{\circ} \mathrm{C}$ for 45 days and at $30 \pm 2{ }^{\circ} \mathrm{C}$ for the following 3 days in absence of light

an absence of change in the initial structure. A higher percentage of SB8 absorption to polyolefin may occur with the most dilute concentration, as the higher percent absorption of immunoglobulin to plastics was noted with the lowest concentration tested [14]. However, the measured protein concentration for all three batches of the low-concentration samples was $1.4 \mathrm{mg} / \mathrm{ml}$ at all time points including day 48 .

In addition to physico-chemical stability, the biological function of SB8 remained intact regarding both binding activity and potency, and no potential safety concerns were noted. Significant change in a drug product is defined as failure to meet the acceptance criteria [15]. The acceptance criteria for appearance, $\mathrm{pH}$, protein concentration, purity and impurity tests, biological activity and potential safety implication were met including particulate matter quantitation for both unopened and opened vial stability. No submicron- or microsize aggregates were noted in the diluted samples. A nucleation leading to aggregation is unlikely because of the absence of high hydrodynamic diameter populations.

A limitation of the study is microbial property assessment [8]. Aseptic conditions were used for all experiments, and aseptic preparation and handling of SB8 are imperative because no preservative is present. As per guidance on maximum shelf-life for unpreserved sterile products for human use after first opening, 
"unless the method of opening/dilution precludes the risk of microbial contamination, the product should be used immediately" [16]. Thus, if not used immediately, in-use storage times and conditions are the responsibility of the user [4]. The critical nuance regarding the applicability of our data is that the sterility of SB8 must be maintained.

Applications of our data are numerous. Our stability data for both unopened and opened SB8 vials as well as diluted solution stability data are valuable to pharmacists who prepare SB8 because temperature excursions and unused drug products do occur. Leftover drug product in vials is likely, as indicated doses of SB8 are weight-based $[1,4]$. An entire vial of SB8 may not be needed, so the ability to use the remaining drug for another patient is invaluable, especially in terms of cost savings from both the drug and preparation perspective. Stability of an opened vial for $72 \mathrm{~h}$ is helpful when re-use of an opened vial is needed after holidays or weekends. Unopened SB8 vials were stable when held at $30 \pm 2{ }^{\circ} \mathrm{C}$ for 30 days starting 36 months after manufacture. The stability of unopened vials at the end of their shelflife and at a much higher temperature than the recommended $2-8{ }^{\circ} \mathrm{C}$ provides confidence to healthcare professionals who have unopened vials that have had a temperature excursion. The stability of diluted SB8 when stored at $5 \pm 3{ }^{\circ} \mathrm{C}$ for 45 days and at $30 \pm 2{ }^{\circ} \mathrm{C}$ for a subsequent 3 days extends the available data provided in both the prescribing information and summary of product characteristics for Avastin $^{\circledR}$. Thus, another application is for advance preparation of diluted SB8, which could facilitate immediate patient treatment and reduce pharmacy workload [7]. Of importance is the fact that the studied storage conditions were extreme. For everyday use, following the storage and stability information in the PI or SmPC is recommended.

\section{CONCLUSION}

The stability of unopened SB8 vials stored lightprotected at $30 \pm 2{ }^{\circ} \mathrm{C}$ with $65 \pm 5 \%$ relative humidity for 1 month and of aseptically opened
SB8 vials stored light-protected at $5 \pm 3{ }^{\circ} \mathrm{C}$ for 3 days was demonstrated. For dilutions prepared aseptically, stability of 48 days when stored at $5 \pm 3{ }^{\circ} \mathrm{C}$ for 45 days and then at $30 \pm 2{ }^{\circ} \mathrm{C}$ for up to $72 \mathrm{~h}$ was demonstrated. These data can be used to support a shelf-life in accordance with national standards, provided that preparation takes place in a controlled and validated environment. The stability data are from extreme conditions and may be helpful for practitioners faced with exceptional situations.

\section{ACKNOWLEDGEMENTS}

The authors thank Dasol Kim, Dayoung Kim, Deahee Kim, Saerom Kim, Sungjae Kim, Un Na, Hyunjung Ryu, Hyerim Park, Byungmin Bae, Suhyeon Eo, Doeyoung Lee, Jungmin Lee, Jimin Lee, Eojin Jung, Eunok Jung, Miju Cho, Sungwon Jo, Jihyeon Han and Jinah Han (quality evaluation team, Samsung Bioepis) for their helpful assistance in performing the test. The authors thank Prof. Irene Krämer and Dr. Judith Thiesen of Pharmacy, University Medical Center Johannes Gutenberg-University Mainz for their review and contribution to the stability study plan.

Funding. Sponsorship for this study and the Rapid Service and Open Access Fees were funded by Samsung Bioepis Co., Ltd. All authors had full access to all of the data in this study and take complete responsibility for the integrity of the data and accuracy of the data analysis.

Medical Writing Assistance. Medical writing assistance was provided by Laurel Riemann, PharmD, BCPS of Med Communications, Inc. (Memphis, TN), and was funded by Samsung Bioepis Co., Ltd.

Authorship. All named authors meet the International Committee of Medical Journal Editors (ICMJE) criteria for authorship for this article, take responsibility for the integrity of the work as a whole, and have given their approval for this version to be published. 
Authorship Contributions. Dongkuk Park, Jihyun Kim, Jihoon Yun, and Su Jin Park) contributed equally to this article.

Disclosures. Dongkuk Park, Jihyun Kim, Jihoon Yun and Su Jin Park are employees of Samsung Bioepis Co., Ltd.

Compliance with Ethics Guidelines. This article does not contain any studies with human participants or animals performed by any of the authors. All SB8 samples were prepared and experiments conducted aseptically in a biological safety cabinet.

Data Availability. The data sets generated during and/or analyzed during the current study are available from the corresponding author on reasonable request.

Open Access. This article is licensed under a Creative Commons Attribution-NonCommercial 4.0 International License, which permits any non-commercial use, sharing, adaptation, distribution and reproduction in any medium or format, as long as you give appropriate credit to the original author(s) and the source, provide a link to the Creative Commons licence, and indicate if changes were made. The images or other third party material in this article are included in the article's Creative Commons licence, unless indicated otherwise in a credit line to the material. If material is not included in the article's Creative Commons licence and your intended use is not permitted by statutory regulation or exceeds the permitted use, you will need to obtain permission directly from the copyright holder. To view a copy of this licence, visit http:// creativecommons.org/licenses/by-nc/4.0/.

\section{REFERENCES}

1. United States Food and Drug Administration. Avastin (bevacizumab)-Prescribing Information [updated 2019]. https://www.accessdata.fda.gov/ drugsatfda_docs/label/2019/125085s331lbl.pdf.
2. European Medicines Agency. Aybintio 2020 https:// www.ema.europa.eu/en/documents/smop-initial/ chmp-summary-positive-opinion-aybintio_en.pdf.

3. Reck M, Luft A, Bondarenko I, Shevnia S, Trukhin D, Kovalenko NV, et al. A phase III, randomized, double-blind, multicenter study to compare the efficacy, safety, pharmacokinetics, and immunogenicity between SB8 (proposed bevacizumab biosimilar) and reference bevacizumab in patients with metastatic or recurrent nonsquamous nonsmall cell lung cancer. Lung Cancer. 2020;146: $12-8$.

4. European Medicines Agency. Avastin ${ }^{\circledR}($ Bevacizumab)-summary of product characteristics 2009 [updated 2020]. https://www.ema.europa.eu/en/ documents/product-information/avastin-epar-prod uct-information_en.pdf.

5. European Medicines Agency. Zirabev TM (Bevacizumab)-summary of product characteristics 2019 [updated 2020]. https://www.ema.europa.eu/en/ documents/product-information/zirabev-epar-prod uct-information_en.pdf.

6. Pivot X, Bondarenko I, Nowecki Z, Dvorkin M, Trishkina E, Ahn JH, et al. A phase III study comparing SB3 (a proposed trastuzumab biosimilar) and trastuzumab reference product in HER2-positive early breast cancer treated with neoadjuvant-adjuvant treatment: final safety, immunogenicity and survival results. Eur J Cancer. 2018;93:19-27.

7. Vigneron J, D'Huart E, Demoré B. Stability studies in oncology. Eur J Oncol Pharm. 2019;2(2):e12.

8. The European Agency for the Evaluation of Medicinal Products Committee for Proprietary Medicinal Products. Note for guidance on in-use stability testing of human medicinal products. 2001. https:// www.ema.europa.eu/en/documents/scientific-gui deline/note-guidance-use-stability-testing-humanmedicinal-products_en.pdf.

9. International conference on harmonisation of technical requirements for registration of pharmaceuticals for human use. Validation of analytical procedures: text and methodology Q2(R1). 1994.

10. International conference on harmonisation of technical requirements for registration of pharmaceuticals for human use. Stability testing of biotechnological/biological products 1995. https:// www.ema.europa.eu/en/documents/scientific-guid eline/ich-topic-q-5-c-quality-biotechnological-prod ucts-stability-testing-biotechnological/biologicalproducts_en.pdf.

11. Santillo MAP, Goddard W, et al. On behalf of the NHS Pharmaceutical Quality Assurance Committee. A standard protocol for deriving and assessment of 
stability, Part 2: aseptic preparations (biopharmaceuticals). 3rd ed. [updated April 2017]. https:// www.sps.nhs.uk/wp-content/uploads/2017/03/Sta bility-part-2-biopharmaceuticals-v3-April-17.pdf.

12. U.S. Department of Health and Human Services Food and Drug Administration. Scientific considerations in demonstrating biosimilarity to a reference product. 2015. https://www.fda.gov/media/ 82647/download.

13. Vlasak J, Ionescu R. Fragmentation of monoclonal antibodies. MAbs. 2011;3(3):253-63.

14. Herrmann JE, Collins MF. Quantitation of immunoglobulin adsorption to plastics. J Immunol Methods. 1976;10(4):363-6.
15. International conference on harmonisation of technical requirements for registration of pharmaceuticals for human use. stability testing of new drug substance and products Q1A(R2) 2003. https:// www.ema.europa.eu/en/documents/scientific-guid eline/ich-q-1-r2-stability-testing-new-drug-subst ances-products-step-5_en.pdf.

16. The European Agency for the Evaluation of Medicinal Products Committee for Proprietary Medicinal Products. Note for guidance on maximum shelf-life for sterile products for human use after first opening or following reconstitution 1998. https://www. ema.europa.eu/en/documents/scientific-guideline/ note-guidance-maximum-shelf-life-sterile-produ cts-human-use-after-first-opening-following_en. pdf. 